\title{
THE JAGGED MEDITERRANEAN SPACE: REGIONS, BORDERS AND SCALARITIES
}

\author{
Claudia Bernardi ${ }^{1}$ \\ Paolo Do
}

\section{Introduction}

Since the 1970s, scholars have deeply spurred to rethink the world within different frameworks that used the space as an analytical tool to understand the complex transformations triggered by globalization ${ }^{3}$ : most of them came up against the limits of a flat comprehension of the political space or a polarization between locality and globality, South and North, national and global, First and Third world, East and West. Conceptual dichotomies or partitions into areas preserve a rigid homogeneity inappropriate to comprehend the drivers or the "subterranean trends" of the present scenarios (Sassen, 2014:5). From this assumption, this paper responds to the need of thinking beyond paradigms and models, considering those approaches able to manage more complex analytical tools from different fields of study, assuming that disciplines in their unity are not capable to grasp the fierce shifts that we are living, even more since the global crisis earthquake: when fault lines break the ground, the space becomes a compass for creating unprecedented territorialities in the new born scenario.

In the first chapter, we consider some methodological tools to provide a prismatic conceptualization of Europe beyond a Eurocentric perspective and through different fields of research. Secondly, we focus on the inner and most important transformations of the European space, the internal/external dimension of European Union (EU) strongly modified by recent policies, the path of migrations and their composition. In the last part, we analyze the constitution of emergent and heterogeneous territorialities along the Mediterranean, defining their scalarities and the neoliberal restructuring taking place in the urban landscape,

\footnotetext{
${ }^{1}$ Claudia Bernardi (Ph.D. in Euro-American Studies) is fellow of the Weatherhead Initiative on Global History at Harvard University, and lecturer in Latin American history at the University of Roma Tre, Italy (clod.zeta@gmail.com).

${ }^{2}$ Paolo Do is Ph.D. in Critical Management and Political Economy at Queen Mary University of London and lecturer in Sociology of Culture at the La Sapienza University of Rome, Italy (paolo.posse@gmail.com).

${ }^{3}$ This paper will not focus on the history or historiographical approaches, but assumes that the period between 1973 to 2008 strongly intensified the globalization and, more than ever, changed the face of our world. For a Marxian understanding of Twentieth century's historical breakup cfr. Negri, 2005; for a thoughtful and non-western comprehension of globalization timeline cfr. Quijano, 2000; for historical problematization of the concept and historiography of globalization cfr. Osterhammel and Petersson, 2009.
} 
where struggle between north and south is more evident: Rome is the case study briefly considered to understand this city as the middle ground of translation of the Mediterranean.

\section{Revising spatiality and challenging relations of the Global}

Nowadays it seems clear that the comprehension of the global space shifted from the classical idea of unity and space/time homogeneity, inherent to the Western nation state and its historiography, to a less stale articulation of focal points that expresses a multiplication of powers and entangling of spaces within a heterogeneous temporal dimension (Chakrabarty, 2000). Whereas the colonial governance attempted to separate inside and outside, citizens and aliens, metropolis and periphery, the struggles for the national independence and the contemporary autonomous movements of migrants have completely disrupted social and spatial hierarchies (Mezzadra, 2008). While the classical dichotomies has being eroded, we are so living an original horizon in which the hierarchies of the past are dislocated to assume new forms, morphed into a multiplication of centers and displaced into a fragmented geography of asymmetrical relations.

These changes require a new logic and methodological resources to examine the global space, taking as first step the dislocation of the notion of West: this concept cannot refer to a specific geographical definition, but to the hegemony and power relationships, historically structured and never given once and for all (Sakai, 1997). In fact, the economic and political power has shifted away from a geographical location called the "West" to a less identifiable position in the "globe" (Wee, 2007). Following this analysis, the dispersal of the "North" into the "globe" represents also a partial decentering of the South. The North, considered as a power relationship, is not homogeneous but is a composition of many variables, none of them remaining constant, in time or space: "it is a composite or assemblage of disparate contexts" (Sakai, 2000). This approach moves our attention from the binary contraposition to a multiple dislocation that expresses the gradient and the vertical positions of subjects-in-relation. We can observe traces of the "South" in the "North", and vice versa: bits and fragments that intervene in local social formations in a systematic, but never totalizing way (Chen, 2009).

Nonetheless, this articulation of fragments risks to appear a sort of puzzled space or subject. Quite the contrary, at the instant when this displacement emerges we can figure out a new set of power shaping a different image of the global territories. In this sense, it is worth to consider the very historical foundation of the relationship between north and south: "Colonization [...] had to be understood then, and certainly can only be understood now, in terms, not only of the vertical relation between colonizer and colonized, but also in terms of how these and other forms of power-relations where always displaced and decentred by another set of vectors" (Hall, 1996). Moving from this evocative reflection, it is possible to understand the pair North/South as an articulated set of vectors able to decentralize and to displace, both spatially and temporally, relationships of dependence and its asymmetries rooted in the global space. The set of vectors identifies the directions and interpenetration of powers, that is to say, the spatialization of the relations of power rooted in the colonial system of dependence. This conceptualization of the space questions us on the present shape of Europe and the "set of vectors" leading it. 
For this purpose, we should consider Europe as a space of translation against the Europe as a translational place: a space shaped by translation as means of political domination, social destruction and property expropriation through a system of filters, hierarchies, and differential management of homogeneity. Translation is especially substantiated into the proper place of the translator, somewhere in between two languages, two cultures or two places that are always already different, that is "naturally" separated before translation arrives to help them connect and communicate each other. It is also a practice taking place in the middle ground, between the different languages and/or cultures aiming to undermine the binary translation theories and the implicit ambivalence implied by this classical opposition (Buden, 2013). The practices of translation can both disrupt current model of Europe and of European hierarchies, such as the South and the North, and sustain the thinking of different subjectivities and relationalities, as well as the rethinking of place and of geographies (Polezzi, 2013). From this perspective, Europe is profoundly heterogeneous and that's why capital itself, affirming its command, works through the articulation and assemblage of different spaces and times. The assemblage is not a locality to which broader forces are counterpoised, instead, it is the product of multiple determinations that are not reducible to a single logic (Collier and Ong, 2008). The temporality of an assemblage is emergent: it does not always involve new forms, but forms that are shifting, "in formation, or at stake", so the term implies a heterogeneity, contingent and unstable temporality of surfacing, whereas global refers to an inherent and seamless tension. It is a dynamic concept that it is useful here to reconceptualize the classical geographies South and North into a global level as a concrete economic complex, partly situated into a specific place. In fact, the global assemblage "has facilitated a logic of accumulation that is selectively applied in diverse political contexts and within specific places” (Glick Schiller and Çağlar, 2011:4).

These considerations lead us to understand the spatial dimension not only in its horizontality, but above all in its vertical dimension: scales result from the vertical differentiation and redifferentiation of social relations "in addition to the «horizontal» or areal differentiation in which social relations are hierarchically articulated among - for example - global, supranationals, national, regional, metropolitan, and local levels" (Brenner, 2011:32). In other words, the scaling and rescaling processes that affect the present global territories serve to conceptualize spatial relationship, power, governance and narrative (Glick Schiller and Çağlar, 2011:6). In fact, theories regarding networks and connections between fragments are still bounded in focusing on the linked pieces, while scaling and rescaling process analyses the same production of hierarchies by those components moving on a vertical dimension. In this way, those territorial units that can be viewed as part of the Global North or Global South are understood in their vertical integration as "sociospatial units of governance", whether coexisting in the same geographical space or not. While the global crisis continuously redefine its long range politics in squeezed time, rescaling approach can identify the ordering of sociospatial units within multiple hierarchies of power recently produced: "rescaling strategies are viewed as a means [...] to establish a new geographical basis for capitalist development and political-economic governance" (Brenner, 2008:29).

North and South are analyzed in relational terms when they coexist geographically, and their transformations can be understood through their variable ordering in the global hierarchy: "rescaling 
processes rework the positionalities of sociospatial formations and thus recalibrate the geographies and choreographies of power relations" (Brenner, 2008:34). Whereas the previous analysis shape the postcolonial dimension of the European space, its decentered position and internal heterogeneity, the models of scalarity are our privileged tool to grasp the complexity and variability of the Mediterranean space that cannot be assigned to the "North", nor to the "South". Instead, it is the core of translation space - the middle ground where practices of mobility and cooperation challenge competitive sociospatial formation imposed by the North.

\section{The entangled European space beyond the limits of E.U.}

In the last twenty years, the European space has been harshly closed into the institutional legacy of the European Union and supranational economic organizations, particularly after the global crisis: this rigid infrastructure is articulated in local economies connected at the global level, regimes of mobility that involve different fluxes of migrants' labor force, and externalized sites of production at the edge of E.U. borders. In short, several economic and political hierarchies shape a motley image of the continent. The progressive “integration" of the European Union's members has not been a smooth or comprehensive process. The multiplication of agreements and treaties have bounded the nations in a complex economic system marked by a neoliberal structure based on the circulation of goods and differentiation of subjects within the social hierarchies in order to maintain its top position in the Global North.

At the same time, this process of integration has been less linear than others whereas E.U. is not a federation or bounded political territory: it is a field for a more dispersed strategy that does not treat the territory as a uniform political space. Market and the E.U. politics driven have produced the fragmentation of the space into various non-contiguous zones, and promote the differential regulation of a population who can be connected to, or disconnected from global circuits of capital (Ong, 2006). In particular, after the so called "Brexit", the nations that are part of the Union have been disarticulated in regions of productions and subjects of forced mobility, that have become the main actors of the present situation. It does not mean that nations have lost their role in the definition of the E.U. strategies, but their function is completely redefined among the neoliberal structure of the Union, working as administrative forces that follow the supranational economic powers and E.U. Commission (Roth and Papadimitrou, 2014). For instance, the image of the political economic structure of the Union is the minimum assumption to analyze the contradictions and infrastructure of its foundation, but it is less useful when we focus on the new emergent scalarities, the overlapping of different and heterogeneous territorialities that are being produced in the current transition, or the specific regimes of mobility affecting populations.

An evocative image to shape alternative figurations of what label "Europe" stands for is the portulan chart: first made in the 13th Century in Italy, and later adopted in Spain and Portugal, they are navigational maps based on compass directions and estimated distances observed, to see what it is constituted, what it includes or excludes, what space is created and what borders insist upon it. These maps are dominated by the fluid space of sea, rather than by land surrounding it, inscribed with multiple connections, intricate links, 
developing relationships that blur any border. These charts take mobility and multiplicity as fundamental elements of history and of experience, recognizes space - including any borders - as permeable, as constituted by and through relationship, and can serve as an icon of the movement of knowledge and people, of individuals and their stories inscribing, at the same time, the mobility into relationships of power (Polezzi, 2013).

In other words, they were charts-on-becoming to define the arising world of modernity and to establish a new logic of space and its measure that lately served to organize the territorial structure more adequate to capital needs: the nation-state. In this sense, portulan charts are useful to query the way in which upcoming Europe is being constructed. In the changing scenario, during this era of transition, the task is to trace the movements of these "choreographies" that have been produced recently in the European space. The emerged powers in the global capitalism are actually the metropolis, global cities that despite the crisis have maintained their leading role as economic drivers linked to migration. A symptom of this complexity is evident when we consider the process of restructuring of the "global cities" inside which the North and the South overlap, not only in their geographical proximity through neighborhoods, but above all in the role that migrants" workforce play in that context: "Migrants evaluate cities and neighborhoods, developing their own hierarchies of places based on the value and prestige of localities within migrant transnational fields" (Glick Schiller and Çağlar, 2011:15). Social actors are active and propulsive drivers of scaling processes and valorization of places that can overturn the division between North and South inside of the Global cities. Recently, Europe has witnessed a scaling process through which the cities of the Global North, such as Berlin, London and Paris, have consolidated their hierarchical position fostering, at the beginning, a strong migration of high skilled young workers from other territories - mainly from Eastern European Countries (EECs) and North Mediterranean Countries (NMCs) - that have strengthened the availability of skilled workers in those cities, and consolidated the fluxes of migration as a mean of cities' restructuring.

According to a recent survey based on the OECD International Migration Database, from 1985 to 2005 the percentage of immigrants with at least some tertiary education grew from $6 \%$ to $19 \%$ in France, from $6 \%$ to $29 \%$ in Germany and from $25 \%$ to $42 \%$ in UK (Docquiera and Rapoport, 2009; Alaminos, Albert and Santacreu, 2010). In the last few years, the increase of young migration from the NMCs to Germany is astonishing: in 2012, the migration from Italy increased by $40 \%$ compared to 2011 , by $45 \%$ from Spain, while from Greece and Portugal registered an increase by 43\% (Redazione Lettera43, 2013). These data assume more importance if considered aside of the percentage of unemployment: graphic 1 gives a clear picture of the strong internal differentiation of the European space through the detailed percentage of unemployment rate between 2004 and 2015. 
Graphic 1

\begin{tabular}{|c|c|c|c|c|c|c|c|c|c|c|c|c|}
\hline & 2004 & 2005 & 2006 & 2007 & 2008 & 2009 & 2010 & 2011 & 2012 & 2013 & 2014 & 2015 \\
\hline Belgium & 8.4 & 8.5 & 8.3 & 7.5 & 7.0 & 7.9 & 8.3 & 7.2 & 7.6 & 8.4 & 8.5 & 8.5 \\
\hline Denmark & 5.5 & 4.8 & 3.9 & 3.8 & 3.4 & 6.0 & 7.5 & 7.6 & 7.5 & 7.0 & 6.6 & 6.2 \\
\hline Germany & 10.4 & 11.2 & 10.1 & 8.5 & 7.4 & 7.6 & 7.0 & 5.8 & 5.4 & 5.2 & 5.0 & 4.6 \\
\hline Estonia & 10.1 & 8.0 & 5.9 & 4.6 & 5.5 & 13.5 & 16.7 & 12.3 & 10.0 & 8.6 & 7.4 & 6.2 \\
\hline Spain & 11.0 & 9.2 & 8.5 & 8.2 & 11.3 & 17.9 & 19.9 & 21.4 & 24.8 & 26.1 & 24.5 & 22.1 \\
\hline France & 8.9 & 8.9 & 8.8 & 8.0 & 7.4 & 9.1 & 9.3 & 9.2 & 9.8 & 10.3 & 10.3 & 10.4 \\
\hline Croatia & 13.9 & 13.0 & 11.6 & 9.9 & 8.6 & 9.2 & 11.7 & 13.7 & 16.0 & 17.3 & 17.3 & 16.3 \\
\hline Italy & 8.0 & 7.7 & 6.8 & 6.1 & 6.7 & 7.7 & 8.4 & 8.4 & 10.7 & 12.1 & 12.7 & 11.9 \\
\hline Cyprus & 4.6 & 5.3 & 4.6 & 3.9 & 3.7 & 5.4 & 6.3 & 7.9 & 11.9 & 15.9 & 16.1 & 15.0 \\
\hline Latvia & 11.7 & 10.0 & 7.0 & 6.1 & 7.7 & 17.5 & 19.5 & 16.2 & 15.0 & 11.9 & 10.8 & 9.9 \\
\hline Netherlands & 5.7 & 5.9 & 5.0 & 4.2 & 3.7 & 4.4 & 5.0 & 5.0 & 5.8 & 7.3 & 7.4 & 6.9 \\
\hline Austria & 5.5 & 5.6 & 5.3 & 4.9 & 4.1 & 5.3 & 4.8 & 4.6 & 4.9 & 5.4 & 5.6 & 5.7 \\
\hline Poland & 19.1 & 17.9 & 13.9 & 9.6 & 7.1 & 8.1 & 9.7 & 9.7 & 10.1 & 10.3 & 9.0 & 7.5 \\
\hline Portugal & 7.8 & 8.8 & 8.9 & 9.1 & 8.8 & 10.7 & 12.0 & 12.9 & 15.8 & 16.4 & 14.1 & 12.6 \\
\hline Romania & 8.0 & 7.1 & 7.2 & 6.4 & 5.6 & 6.5 & 7.0 & 7.2 & 6.8 & 7.1 & 6.8 & 6.8 \\
\hline Slovenia & 6.3 & 6.5 & 6.0 & 4.9 & 4.4 & 5.9 & 7.3 & 8.2 & 8.9 & 10.1 & 9.7 & 9.0 \\
\hline Slovakia & 18.4 & 16.4 & 13.5 & 11.2 & 9.6 & 12.1 & 14.5 & 13.7 & 14.0 & 14.2 & 13.2 & 11.5 \\
\hline Finland & 8.8 & 8.4 & 7.7 & 6.9 & 6.4 & 8.2 & 8.4 & 7.8 & 7.7 & 8.2 & 8.7 & 9.4 \\
\hline Sweden & 7.4 & 7.7 & 7.1 & 6.1 & 6.2 & 8.3 & 8.6 & 7.8 & 8.0 & 8.0 & 7.9 & 7.4 \\
\hline United Kingdom & 4.7 & 4.8 & 5.4 & 5.3 & 5.6 & 7.6 & 7.8 & 8.1 & 7.9 & 7.6 & 6.1 & 5.3 \\
\hline Iceland & 3.1 & 2.6 & 2.9 & 2.3 & 3.0 & 7.2 & 7.6 & 7.1 & 6.0 & 5.4 & 5.0 & 4.0 \\
\hline Norway & 4.3 & 4.5 & 3.4 & 2.5 & 2.5 & 3.2 & 3.6 & 3.3 & 3.2 & 3.5 & 3.5 & 4.4 \\
\hline Turkey & : & 9.5 & 9.0 & 9.1 & 10.0 & 13.0 & 11.1 & 9.1 & 8.4 & 9.0 & 9.9 & 10.3 \\
\hline
\end{tabular}

Source: EUROSTAT, 2016.

But quantity is not the most relevant element of the migration flow, as stressed by the same German Minister of Labor Ursula von der Leyen: «It is not only about numbers; our fortune is about the quality of this migration that helps our Country to become younger, more creative and more international one» (Ciolli, 2013). In fact, the composition of migrants heading Germany is mostly high skill, so as those in United Kingdom, but despite being skilled workforce most of them are employed in medium or low skill sectors. "Appendix A" of the Overview of EaP migrant profiles, based on country studies, shows that the high skill migrant workforce in Germany is the $44 \%$ of the total flow and just $34 \%$ is employed in high skill occupation; while in UK the high skill migrant labor force is $53.5 \%$ and just $21.7 \%$ is employed in high skill occupations (Barbone, Kahanec, Kurekova and Zimmermann, 2013; cfr. Zaiceva and Zimmermann, 2008:4).

This downgrading shows how the wider European space is facing a process of internal hierarchization in which migrants from NMCs have been relegated in a subordinate position through segmentation of the labor market: a "mobile South" inside the metropolis of the Global North.

Furthermore, the migration from the so called post-socialist and post-soviet countries towards Germany, in particular, have continuously and strongly pushed over the historical division between West and East, well represented by the Berlin wall. Whereas the boundary fell down decades ago, the immaterial distinction between the "democratic" West and the "barbarian" East endures and has been turned into the material border of the VISA system that continuously depicts the eastern population as the bottom group of the European hierarchy (Cherepanyn, 2013). Actually, a recent declaration of Chancellor Angela Merkel are a clear sign of an upcoming border: "The E.U. is not a social Union" (Seiffert, 2014), clearly stating the 
impossibility to tie labor and welfare, mobility and social guarantees, valorization of migrants' skills and fair long-term wages.

At the same time, since the 1990s "Spain and Italy emerged as the main new destinations for labor migrants from the southern Mediterranean” (de Haas, 2011:61). Above all after the Arab Spring, a strong migration from SMCs headed towards Europe, even when refugees aim to reach the Northern European countries, the Dublin System (I and II) has imposed a fierce filter to the internal mobility, with the aim of regulating the external immigration, that made actually impossible to leave the country of arrival (EURlex). Briefly, while the Schengen system allows internal temporary migration of high skill workers, the Dublin's one maintain the low skill workers, coming from the external peripheries, inside the internal fringes of the continent, such as Athens and Rome. Borders control, through Frontex patrolling, and the construction of "defensive" walls - between Greece and Turkey, Spain and Morocco, Austria and Hungary - have marked the European space and implemented the construction of hierarchies. But, "rather than curbing migration, this has caused a diversification of trans-Saharan migration routes and Mediterranean crossing points which now span almost the entire Mediterranean" (de Haas, 2011:61).

It is so possible to observe a multiplication of differences inside the homogeneous "European Fortress”. It is a process of displacement and multiplication of hierarchies that produces contradiction, displacing new frictions within the skilled and young workforce based on asymmetries that are globally displaced: the mobility of skilled young workers and the creation of boundaries and hierarchies represents, at the same time, this decentralization and multiplication. While differences are configured as asymmetries and imbalances, the European Union is a powerful code of de-territorialization and re-territorialization, a source of innovative geographies spatially dispersed and globally integrated. The non-linear relation between the North and South is also related to this displacement and the multiplication of filters and borders, and useful for describing and analyzing how the mobility of labor force can be subject to varying degrees of subordination, rule, discrimination, and segmentation.

The inner difference between the assemblage of territory, authority, and rights in the state system of mobility control, on one hand, and in the European space, on the other, is that Europe does not exist as a space that can be identified by establishment of fixed and solid borders. Europe exists as a legal and political space (i.e. a space autonomous from the sum of the member states' territories) only to the extent that it is circulated, whether this means the circulation of goods, people, or rights (Karakayali and Rigo 140).

Under the ruling of Troika it is emerging a recent dispositive in Europe: a "scalar device" of workforce mobility that is deeply changing the North/South divide in the West as well as at the global level. Europe is featured by continuous overlapping and differentiations between the "South of the North" and the North, assemblages and combinations, influences in the distance and effects that deal with a new exploitation deployed in a diffuse environment, instead of within the narrow boundaries of classical geography dimension. Within the opposition between North/South, there is the old problem of boundary and classification. It is the portulan chart of the crisis that can draw an ambiguous map, able to recognize the presence of new borders and discriminatory regimes, questioning the orthodoxy that categorizes the global spectrum of labor according to the international division of stable configuration (Sakai, 2013). 


\section{The jagged Middle-South}

The Mediterranean is a case study that well illustrates the shifting formation of the global space, within a changeable scalarity and shifting classification that complicate a linear division between Global South and Global North, as the NMCs are facing a fierce period of unemployment, indebtment and impoverishment. According to Eurostat, last year in Greece, more than one in two people aged under 25 was unemployed, a staggering rate of $58.4 \%$. In Spain, the rate is $55.7 \%$, followed by Portugal with $38.2 \%$ and Italy at $37.8 \%$ (Spiegel Online International, 2013).

Even though Italy is still considered a wealthy nation and prominent member of the West/Global North, the increasing process of impoverishment pursued by crisis, neoliberal and austerity measures has modified intensively the social structure of the country. ${ }^{4}$ Beyond young unemployment, just analyzed in the previous chapter of this paper, even the process of general impoverishment is a useful indicator of their effects: between 2005 and 2007 poverty affects $11.1 \%$ of the population, increasing till 17\% in 2011, and even 20.5\% in 2013 (ISTAT, 2014). Rather than diminish, poverty is a growing phenomenon that affects particularly the adult part of the population that should be already employed in the formal labor market, but still young and active. Among the many effects, these policies produced a growing number of working poor and strong emigration of high-skill young work force towards the north of Europe, not only because of high rate of young unemployment, but above all for better condition of life and possibilities of desires' fulfillment in other countries. In 2013, migration to Northern Europe (in particular Germany, France, Belgium and UK) increased by $19.2 \%$ compared to 2012 , and 55\% compared to 2011 (Corriere della Sera, 2014).

Moreover, among the 20 million graduates of the OECD, just $0.7 \%$ of them chose Italy as destination country, less than Turkey (Stella, 2009). At the same time, Italy it is still the territory of arrival of low skill labor force from SMCs, as affirmed by Eurostat data, that in 2013 for the first time does not balance out the emigration of Italian citizens towards other countries. The percentage of immigrant with a degree is $12.2 \%$, the lowest among the OECD countries, far below the overall average, 23.2\%, and of the European countries, 18.6\% (Crivellaro, 2014).

As we have witnessed for Europe at large, even the Mediterranean space is involved in a deep re/scaling process of cities' restructuring, as they are "sites of substantiation and contestation of hierarchies of global-spanning power" (Glick Schiller and Çağlar, 2011:18). The transformation of the NMCs' cities is emblematic of the overlapping of North and South. In the last decade, most of them have faced an acceleration of the privatization process, the reduction of the public spaces, the dismantling of health and welfare structures, the gentrification of migrants and students' neighborhoods. The city itself has changed its function becoming a "brand" to sell in the global market of tourism, in which the historical city centers are the best goods available. Between 2007 and 2011, Rome has been visited more by non-EU tourists - in

\footnotetext{
${ }^{4}$ We refer in particular to the Education reform (promoted by Minister Gelmini during the fourth Berlusconi's government) that in 2009 drastically cut the funds of public education, for the benefit of the private one, stopped researchers' turnover and reduced the number of department and fields of study in the university. Secondly we refer to the so called "Decreto salva Italia" (Save Italy Decree) approved on December 2011: a series of laws that comprehend the reform of retirement system, tax withholding on houses and salaries, the raise of taxes on consume goods.
} 
particular from Russia (+466\%), Japan (+60\%) and Canada (+50\%) - and less by EU tourists with a sensible decrease of German tourists by nearly $30 \%$ (ISTAT, 2014).

At the same time, the consolidation of migrants' networks and the expansion of their commercial activities, as happened in Rome in the last decade, have revitalized those popular and poor neighborhoods placed in the peripheries of the city: to the opening pursued by SMCs' migrants has followed immediately a process of gentrification, mixed with a quasi-feudal corporative management of the city and the ongoing process of precarization.

One of the best examples of this process can be considered Pigneto neighborhood placed in the SouthEast part of the city, outside of the historical center and inside city's ring road; built up between 1870s and 1930 , it was intensively populated in the 1950s mainly by poor Italian migrants and manual laborers (Severino, 2005). Whereas, it was a poverty-stricken periphery - a suburb of the post-war economy animated by political militants and location of neorealism movies - since the 1990s it has become one of the main settlement area of migrants, in particular from Bangladesh, Senegal and Romania added to the older Chinese community (Scandurra, 2007). Stimulated by house rental low prices and proximity to university and main city station, migrants choose the area to develop their commercial activities and raise their children in the primary school strictly connected to the social territory, transforming Pigneto from an historical neighborhood to the "Banglatown" of Rome (Pompeo, 2011): part of the eternal-city, proud of its brownness and attraction for students and European artists in 2000s. As soon as this process of scalarity took place, the neighborhood has been hit by governance policies and real estate market investments, causing a harsh gentrification synthetized in the slogan "Pigneto Village" (Pompeo, 2011:42-55; Scandurra, 2007). This process lead to the rising of rental price, the evictions of social spaces and the fierce speculation on estate market: a process that has been compared to those of Kreuzberg in Berlin, Williamsburg in New York, Brick Lane in London to highlight its global character (Mubi-Brighenti, 2010; City Regional Planning, 2008).

In this context, the portulan chart of the Mediterranean is quickly changing under the aggressive pressures of the neoliberal and austerity measures, combined with the "commissarial dictatorship" of Troika (Balibar, 2011), and the rhetoric of national governments that foreshadow an exit strategy based on the needed sacrifices of the "South". To the imposition of the corporate economic growth as mean to change the cities' position in the global hierarchy, movements of migrants and high skill young have answered in different ways. To the expansion of Global North policies, the lower classes have created experiences of selfmanaged spaces, networks of transnational connections and widespread resistance (Queirolo Palmas and Lagomarsino, 2007), that is to say, there is no linearity in the application of such measures that could be considered the imposition of the Global North upon “its Souths" and, despite capital's aggressiveness, there are ongoing processes of regeneration unbounded by neoliberal governance even if located in the Global economy.

This political and spatial change could be well-explained by the words of Greek artist Miltos Manetas: "In the Western territories of the Northern World and mostly Europe, a new Middle South is born. This new Middle-South is already visible in the self-transforming territories such as Greece and Italy below Rome” (Manetas, 2012). The jagged Mediterranean space is a Middle-South, where the always changing scalarities of 
the Global North are actively operating to fragment territories, select their populations, and including differentially part of the South. In other words, there is no pure or linear definition of the South or its members, and the vectors of spanning global power are involved in a worldwide and bodily expansion in which everybody, at diverse degrees, is part of it. But, we are actually observing the current emergence of the MiddleSouth: a middle ground of translation where South and North struggle. In the Middle South, North is rooted, but not completely accepted, it is spatially diffused through the strategies of grabbing and appropriating, but not given or all-powerful. At the same time, the mobile South is strongly capable to find escape routes through their autonomy of migration (Papadopolous et al., 2008) that subvert and create new scalarities, creating continuously practices of resistance to the neoliberal measures, trying to figure out innovative forms of mutualism and self-production to re/use resources and not just consume it. In brief, the Middle-South is the practice of creating territorialities through a common use of our life, skill and space, within the North, but not dependent or constraint by its policies.

\section{Conclusion}

We are facing an original displacement of the classical dependency between South and North, an articulation of forces and contradictions, asymmetries and differential positions in the geographies of labour exploitation, access to welfare and citizenship. North and South can be considered as two simplifying labels of our analytical compass that work as spatial "highlighter" of differences and frictions. In this framework, Europe is a territory that does not coincide with the legal boundaries of the Union and its borders. Crisis drafted a new regional configuration of multiple forces interconnected, crossed by a spatial reorganization and policies between center and periphery, north and south, east and west, thus showing asymmetries that have been radicalized during the crisis. This is parallel by the multiplication of internal and external borders, in addition to the new centrality of the so-called margins.

The global space, despite being a sum of nation states or the division between distinct areas of hegemony, it is a jagged space, characterized by an entanglement of regions, mobility corridors, multiplication of borders, frontiers of capital, global cities and zone of interactions, where South and North continuously overlap, struggle and coexist one into the other.

So as, we are observing a radical transformation of the spatial coordinates of Europe that make the notion of European space adopted in recent years if not more useful, at least not very effective. The European labor market of young workforce, more and more is characterized by an increasingly tie to an inter-regional mobility and continental spatiality, defined by the status and the role of knowledge, creating filters and original social hierarchies from disruptive effects. It is a selective mobility for this young workforce that embedded skills for the high value sector of the capitalistic production. New selective process related to skills, mobility and geographical origin produce cognitive hierarchies, even harsher and more effective, giving rise to a systemic production of geo-institutional differentiation. Europe emerges such as a relatively new device for mobility embodied in the geographical, generational and skills of the young workforce. 
The challenge is still and more important than ever "to trace the ways in which such scaled politicaleconomic orders structures (i.e. at once constrain and enable) social relations of power, domination, exploitation, and struggle" (Brenner, 2011:35). The experience of transformation in the Middle-South constitutes the evident ineffectiveness of dichotomist conceptual tools and the continuous production of scaling processes by movements and conflicts within the Middle-South, where the southern self-transforming territorialities are crossed by the northern borders and by the North's devices of appropriation in the fragmented globalized space.

\section{BIBLIOGRAPHY}

ALAMINOS, Antonio, ALBERT María Carmen and SANTACREU Óscar. 2010. La movilidad social de los emigrantes españoles en Europa. Revista Española de Investigaciones Sociológicas. 129 (EneroMarzo): 13-35.

BALIBAR, Etienne. 2011. Europe's revolution from above. Guardian. London, 23 November. Available at <www.theguardian.com/commentisfree/2011/nov/23/europe-revolution-from-above>. Access on 10 May 2014.

BARBONE, Luca, KAHANEC Martin, KUREKOVA Lucia and ZIMMERMANN F. Klaus. 2013. Overview of EaP migrant profiles based on country studies. Migration from the Eastern Partnership Countries to the European Union - Options for a Better Future. Research Report. 55, IZA,.

BRENNER, Neil. 2011. The Urban Question and the Scale Question. Some Conceptual Clarifications. In: GLICK SCHILLER, Nina; ÇAĞLAR, Ayşe. Locating Migration. Rescaling Cities and Migrants. 23-41. New York: Cornell University Press.

BUDEN, Boris. 2013. Translating beyond Europe. transversal/EIPCP: A communality that cannot speak: Europe in translation. June. Available at < http://eipcp.net/transversal/0613/Buden/en>. Access on March 2014.

CHAKRABARTY, Dipesh. 2000. Provincializing Europe. Postcolonial Thought and Historical Difference. Princeton: Princeton University Press.

CHEN, Kuan-Hsing. 2009. Editorial introduction. Inter-Asia Cultural Studies. 10 (2): 179-180.

CHEREPANYN, Vasyl. 2014. L'altro lato dell'Europa. In BERNARDI, Claudia; BRANCACCIO, Francesco; FESTA, Daniela; MENNINI, Bianca Maria. Fare spazio. Pratiche del comune e diritto alla città. P. 159168. Milano: Mimesis.

CIOLLI, Barbara. 2013. L'immigrazione selettiva della Germania. Lettera 43. Rome, 8 May. Available at <www.lettera43.it/economia/macro/l-immigrazione-selettiva-della-germania_4367594237.htm >. Access on 20 August 2014.

CITY REGIONAL PLANNING (CRP). 2008. Il Pigneto. Rome Planning workshop. Cornell University in Rome, Spring.

COLLIER, J. Stephen; ONG Aihwa. 2008. Global Assemblages: Technology, Politics, and Ethics as Anthropological Problems. New York: John Wiley \& Sons.

REDAZIONE ONLINE. 2014. Sono 4.4 milioni gli italiani all'estero. Corriere della Sera. 7 March. Available at <www.corriere.it/scuola/14_marzo_07/sono-43-milioni-italiani-all-estero-c-chi-va-fare-stagistacina-992f2a96-a5e6-11e3-b663-a48870b52ff3.shtml>. Access on 21 August 2014. 
CRIVELLARO, Elena. 2014. Fuga dei cervelli, la nuova diaspora italiana?. Il Fatto Quotidiano. 15 April. Available at <www.ilfattoquotidiano.it/2014/04/15/fuga-dei-cervelli-la-nuova-diasporaitaliana/952335/ >. Access on 21 August 2014.

DANIELE, Ulderico. 2011. Élite territoriali, governance locale e spazi di protagonismo dei migranti. In POMPEO, Francesco. Pigneto Banglatown: migrazioni e conflitti di cittadinanza in una periferia di Roma. P.119-138. Roma: Meti.

DE HAAS, Hein. 2011. Mediterranean Migration Futures: Pattern, Drivers and Scenarios, Global Environmental Change. 21S, 59-69.

DOCQUIERA, Frédéric; RAPOPORT, Hillel. 2009. Quantifying the Impact of Highly-Skilled Emigration on Developing Countries. CEPR project-Fondazione Rodolfo De Benedetti. Available at <www.frdb.org/upload/file/Docquier.pdf $>$. Access on 21 August 2014.

DOUZINAS, Costas; PAPACONSTANTINOU, Petros. 2011. Greece is standing up to EU colonialism. The Guardian. 27 June. Available at <www.theguardian.com/commentisfree/2011/jun/27/greece-bailouteu-neocolonialism>. Access on 25 August 2014.

EUROSTAT. 2011. Migrants in Europe. A statistical portrait of the first and second generation. Luxembourg: Publication Office of the European Union.

EUROSTAT. 2016. Unemployment rate 2004-2015 (\%). EUROSTAT. Available at <http://ec.europa.eu/eurostat/statistics-explained/index.php/File:Unemployment_rate_20042015_(\%25)_new.png\#filelinks>. Access on 8 February 2016.

GLICK SCHILLER, Nina; ÇAĞLAR Ayşe. 2011. Locating Migration. Rescaling Cities and Migrants. New York: Cornell University Press.

HALL, Stuart. 1996. When was the 'Postcolonial'? Thinking at the Limit. In CHAMBERS, Iain; CURTI, Lidia. The Post-colonial Question: Common Skies, Divided Horizons. 242-259. London: Routledge.

ISTAT. 2014. Condizioni economiche delle famiglie e disuguaglianza. ISTAT. Available at <www.istat.it/it/condizioni-economiche-delle-fami.>. Access on 22 August 2014.

ISTAT. 2014. Il turismo internazionale dell'Italia. ISTAT. Available at <www.istat.it/it/archivio/turismo>. 2014. Access on 22 August 2014.

KANDYLIS, George; MALOUTAS Thomas; SAYAS, John. 2012. Immigration, inequality and diversity: socioethnic hierarchy and spatial organization in Athens, Greece. European Urban and Regional Studies. 19 (3). 267- 286.

KARAKAYALI, Serhat; RIGO, Enrica. 2010. Mapping the European Space of Circulation. In DE GENOVA, Nicholas; PEUTZ, Nathalie, The Deportation Regime: Sovereignty, Space, and the Freedom of Movement.123-146. Durham\&London: Duke University Press.

MANETAS, Miltos. 2012. Manifesto for Art in Middle South. P/Act for Art. 10 May. Available at <www.solidarityaction.istitutosvizzero.it/?p=633\&lang=en>. Access on 21 April 2014.

MEZZADRA, Sandro. 2008. La condizione postcoloniale: Storia e politica nel presente globale. Verona: ombre corte.

MUBI-BRIGHENTI, Andrea. 2010. The paradoxes of Urban Authenticity. Metropolitiques. 25 November. Available at <www.metropolitiques.eu/The-Paradoxes-of-Urban.html>. Access on 22 August 2014.

NEGRI, Antonio. 2005. Fine Secolo: Un'interpretazione del Novecento. Roma: ManifestoLibri.

ONG, Ahiwa. 2006. Neoliberalism as exception: mutations in citizenship and sovereignty. Durham: Duke University Press. 
OSTERHAMMEL, Jürgen; PETERSSON P. Niels. 2009. Globalization. A short history. Princeton: Princeton University Press.

PAPADOPOULOS, Dimitris; VASSILIS, Tsianos. 2008. Escape routes: Control and Subversion in the TwentyFirst Century. London: PlutoPress.

POLEZZI, Loredana. 2013. Disrupting Europe: Polylingual Models and Common Selves. transversal/EIPCP: A communality that cannot speak: Europe in translation. June. Available at <http://eipcp.net/transversal/0613/polezzi/en>. Access on March 2014.

POMPEO, Francesco. 2011. Pigneto Banglatown: migrazioni e conflitti di cittadinanza in una periferia di Roma. Roma: Meti.

QUEIROLO PALMAS, Luca; LAGOMARSINO Francesca. 2007. Hermanitos: Vita e politica di strada tra i giovani latinos in Italia. Verona: ombre corte.

QUIJANO, Anibal. 2000. Coloniality of Power, Eurocentrism, and Latin America. Nepantla. Views from the South. 1 (3). 533- 580.

REDAZIONE LETTERA43. 2013. Italiani in Germania. Lettera43. 7 May. Available at <www.lettera43.it/economia/macro/italiani-in-germania-40-nel-2012_4367594106.htm>. Access on 20 August 2014.

ROTH, Karl Heinz; PAPADIMITROU, Zissis. 2014. Manifesto per un’Europa egualitaria: Come evitare la catastrofe. Roma: DeriveApprodi.

SAKAI, Naoki. 2000. 'You Asians': On the Historical Role of the West and Asia Binary. The South Atlantic Quarterly. 99 (4):789-817.

SAKAI, Naoki. 1997. Translation and Subjectivity: On "Japan” and Cultural Nationalism. MinneapolisLondon: University of Minnesota Press.

SAKAI, Naoki. 2013. The Microphysics of Comparison towards the Dislocation of the West. transversal/EIPCP: A communality that cannot speak: Europe in translation. June. Available at <http://eipcp.net/transversal/0613/sakai1/en>. Access on March 2014.

SASSEN, Saskia. 2014. Expulsions: Brutality and Complexity in the Global Economy. Cambridge: Harvard University Press.

SCANDURRA, Giuseppe. 2007. Il Pigneto: Un'etnografia fuori le mura di Roma. Le storie, le voci e le rappresentazioni dei suoi abitanti. Padova: CLEUP.

SEIFFERT, Jeanette. 2014. Merkel's EU is not a social welfare union. DW. 23 May. Available at <www.dw.com/en/merkels-eu-is-not-a-social-welfare-union/a-17656430 >. Access on 1 June 2014.

ŞENEL, Aslihan. 2013. Mapping as Performance: an Alternative to Authoritative Representations of Istanbul. iQuaderni. 3. 85-94.

SEVERINO, G. Carmelo. 2005. Roma mosaico urbano: Il pigneto fuori Porta Maggiore. Roma: Gangemi.

SEZER, Kamuran. 2009. Generation Heimweh Die türkischen Akademiker und Studierenden im Kontext des Fachkräftemangels. Heinrich Böll Stiftung. Heimatkunde Migrationspolitisches portal. 1 September. Available at <https://heimatkunde.boell.de/2009/09/01/generation-heimweh-dietuerkischen-akademiker-und-studierenden-im-kontext-des >. Access on 21 August 2014.

SPIEGEL INTERNATIONAL. 2013. Record High: European Jobless Rates Show North-South Rift. Spiegel Online International. 2 April. Available at <www.spiegel.de/international/europe/euro-zoneunemployment-hits-record-high-a-892137.html>. Access on 21 August 2014.

STELLA, Gian Antonio. 2009. I laureati stranieri snobbano l'Italia. Ne arrivano di più in Turchia. Corriere della

Sera. 
<www.corriere.it/cronache/09_maggio_20/laureati_stranieri_stella_2902733a-450c-11de-982b00144f02aabc.shtml>. Access on 21 August 2014.

WEE, C. J. Wan-Ling. 2007. The Asian modern: culture, capitalist development. Singapore: NUS Press.

ZAICEVA, Anzelica; ZIMMERMANN F. Klaus. 2008. Scale, diversity, and Determinants of Labour Migration in Europe. Discussion Paper n.3595. Bonn: Study of Labor (IZA), July. 


\section{RESUMO}

Este artigo fornece uma conceituação prismática da Europa, para além de uma perspectiva eurocêntrica, para investigar a sobreposição do Norte e do Sul dentro dela, considerando o Mediterrâneo e a cidade de Roma como caso exemplar.

Palavras-clave: Espaço, Sul Global, Mediterrâneo;

\section{ABSTRACT}

This paper provides a prismatic conceptualization of Europe, beyond a Eurocentric perspective, to investigate the overlapping of the North and South within it, considering the Mediterranean and the city of Rome as exemplary case.

Key-words: Space, Global South, Mediterranean; 